\title{
Designing Wildlife Corridor Along Cikapundung River in Bandung Urban Area (Indonesia) based on Comparation with Kamo River in Kyoto (Japan)
}

\author{
Evita Izza Dwiyanti ${ }^{1,2}$, Shozo Shibata ${ }^{1}$, Ryo Nukina ${ }^{1}$, Tien Lastini $^{2 *}$, Endang Hernawan ${ }^{2}$ \\ ${ }^{1}$ Landscape Ecology and Planning, GSGES, Kyoto University, Kyoto, Japan \\ ${ }^{2}$ Biomanagement, School of Life Science and Technology, Bandung Institute of Technology, Bandung, Indonesia
}

\section{ARTICLE INFO}

\section{Article history:}

Received January 2, 2020

Received in revised form November 17, 2020

Accepted November 30, 2020

\section{KEYWORDS:}

Cikapundung River,

wildlife corridor,

landcover,

river border

\begin{abstract}
Cikapundung is a river connecting wildlife habitat in two open green space areas; there are Tahura Djuanda and Bandung Zoo. Now, these habitats are fragmented due to intervention by urban activities in the Cikapundung River boundary. One of the proposed solutions is to develop a wildlife corridor along the Cikapundung River. The purpose of this study is to identify the landcover of the Cikapundung River, analyze the potential area which can be developed into a wildlife corridor, designing the landscape of the corridor tailored to the needs of the wildlife, and comparing the condition of the Cikapundung River boundary with Kamo River in Kyoto, Japan. Primary data is landcover of Cikapundung River boundary obtained through on-screen digitizing from satellite imagery using ArcMap. Secondary data are the biodiversity list in Cikapundung River riparian area and its ecological description. Cikapundung River border has several land cover types; the highest percentage of the landcover is tree canopy $62.2 \%$, followed by buildings $31.0 \%$. As a result of the comparison Cikapundung River has a more significant vegetation species; however, Kamo River has a more significant number of wildlife species. In the design planning, 14 vegetation species have been selected according to 26 target wildlife species' needs.
\end{abstract}

\section{Introduction}

Biodiversity is defined as all living things on earth, including all types of plants, animals, and microbes whose existence are interconnected and require one another to grow and develop to form a living system. Indonesia is a country with a high level of biodiversity, but yet also has the highest threat and extinction of species in the world. One of the causes is habitat fragmentation (Soedrajat 1999; Kusmana and Hikmat 2015).

Habitat fragmentation is a process that occurs when a large landscape of habitat is transformed into some smaller area habitat patches that are isolated by an unoriginal habitat matrix (Fahrig 2003). Habitat fragmentation can occur due to dividing areas for roads, agricultural land, urban areas, or settlements. Habitat fragmentation has a severe impact on wildlife conservation because wildlife species cannot move and disperse outside their habitat (Elliot et al. 2013). One

\footnotetext{
* Corresponding Author

E-mail Address: tien@sith.itb.ac.id
}

example of a habitat fragmentation case is the separation of wildlife habitat in Taman Hutan Raya Ir. H. Djuanda (Tahura) with habitat in the Bandung Zoo area. These habitats are open green space areas in Bandung, which Cikapundung River connects. According to Suryawan (2011), there has been an increase in intervention by urban activities in the Cikapundung River boundary. Likewise, it was also mentioned by Devi (2017) that the riparian vegetation is diminishing due to the conversion of riparian areas into human building areas. There are around 1085 residential buildings on the Cikapundung River boundary. Vegetation only covers some areas upstream, while in the middle and downstream are dominated by buildings. In some areas, much dense housing is built irregularly in slum conditions (Figure 1).

The solution proposed by Elliot et al. (2013) is to build a wildlife corridor. Wildlife corridors will reconnect separated habitats and facilitate wildlife to move and disperse from one habitat patch to another. Evidence shows the benefits of building a wildlife corridor that can exceed their weakness, like establishing an area for 'shooting galleries', encouraging wildlife out from 
conservation areas' safety, and making easy targets for hunters. In Costa Rica, the riparian wildlife corridor has successfully reconnected fragmented bird populations, and in Australia, it has been confirmed that genetic mixing has re-occurred among small mammal species even though only through the construction of narrow corridors. Also, in Australia, the development of abandoned forests for wildlife corridors with a width of 30-40 meters is known to support arboreal mammals' movement. Based on those facts and evidence, the proposal of developing a wildlife corridor along the Cikapundung river boundary can be implemented as an effort for environmental rehabilitation.

Another reason that can support and strengthen the wildlife corridor development plans is based on the Bandung Spatial and Regional Planning 2011-2031 (Rencana Tata Ruang dan Wilayah/RTRW Kota Bandung) by Bandung City Government, which state that the Cikapundung River boundary is designated as a Protected Area Plan (Rencana Kawasan Lindung/RKL) in the Local Protection Area (Kawasan Perlindungan Setempat/KPS), so the border of Cikapundung River (right-left distance at least 10 meters) is supposed to be a green line that must be preserved for its function. The designation of wildlife corridor also can increase the percentage of open green space (Ruang Terbuka Hijau/RTH) in the city. From the Indonesian Law Number 26 of 2007 about Spatial Planning, the minimum percentage target for open green space area in a city is 30\% meanwhile Bandung's achievement in 2018 is only 12.21\% (Humas Kota Bandung 2018). Therefore, designing a wildlife corridor in the Cikapundung River boundary is a proper
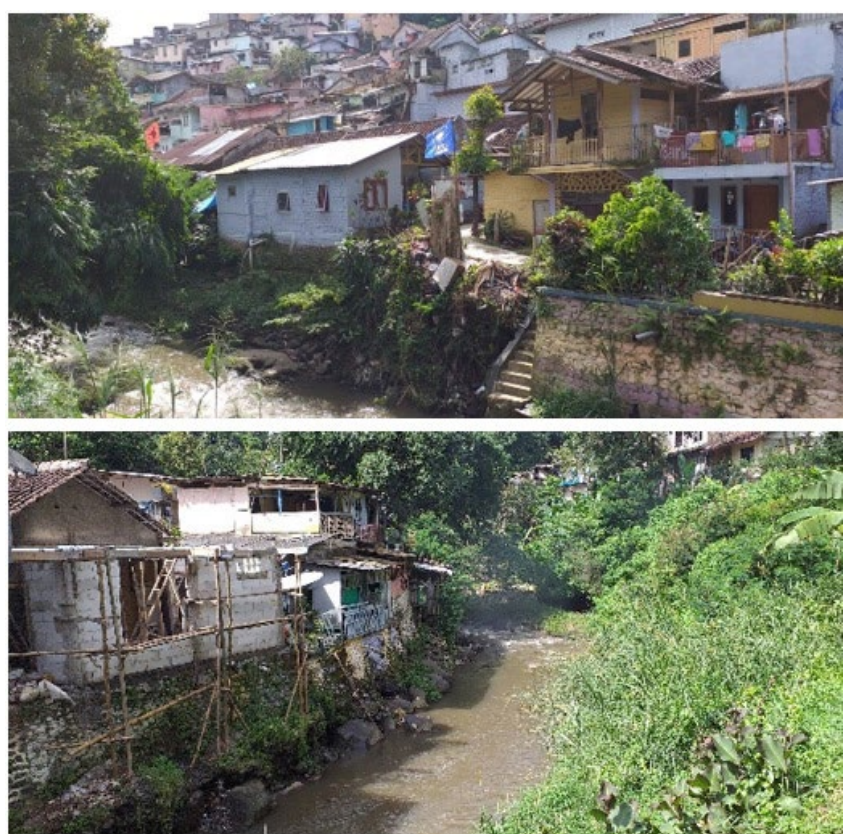

Figure 1. Current condition of Cikapundung river boundary 2019 (source: personal documentation) designation to meet the requirements of the Bandung City Spatial Plan, reaching the Indonesian government's target, and the most important is to reconnect the two separated habitats so the biodiversity can be protected from environmental damage due to the dominance of human-made landscape.

The purpose of this study is to identify the landcover of the Cikapundung River boundary to understand the current condition and to analyze the potential area which can be developed into a wildlife corridor, comparing the condition of the Cikapundung River boundary with Kamo River in Kyoto, Japan, and designing the landscape of the corridor tailored to the needs of the wildlife.

\section{Materials and Methods}

\subsection{Study Area}

Cikapundung River is located in Bandung City, West Java, Indonesia (Figure 2). This river is a sub-watershed of Citarum River. Total Cikapundung River length is $\pm 25.0 \mathrm{~km}$, and $\pm 15.5 \mathrm{~km}(68 \%)$ of it is crossing the Bandung City. The main study area is along the border of Cikapundung River with a length of $7.5 \mathrm{~km}$, starting from coordinates $6^{\circ} 53^{\prime} 56.27^{\prime \prime} \mathrm{S}$ and $107^{\circ} 36^{\prime} 22.84^{\prime \prime} \mathrm{E}$ to $6^{\circ} 51^{\prime} 19.47^{\prime \prime} \mathrm{S}$ and $107^{\circ} 37^{\prime} 48.22^{\prime \prime} \mathrm{E}$. This area is included in the administrative areas of sub-districts Coblong and Cidadap. Kamo River is located in Kyoto-shi, Japan. The length of the Kamo River is about $31 \mathrm{~km}$ (Luo et al. 2013). The average of the river border width is $45.25 \mathrm{~m}$ (calculated from the study area, using remote sensing). The study area is started from $35^{\circ} 2 ' 20.27 " \mathrm{~N}$ $135^{\circ} 45^{\prime} 58.99 " \mathrm{E}$ to $35^{\circ} 1$ '25.03"N $135^{\circ} 46^{\prime} 16.61$ "E.

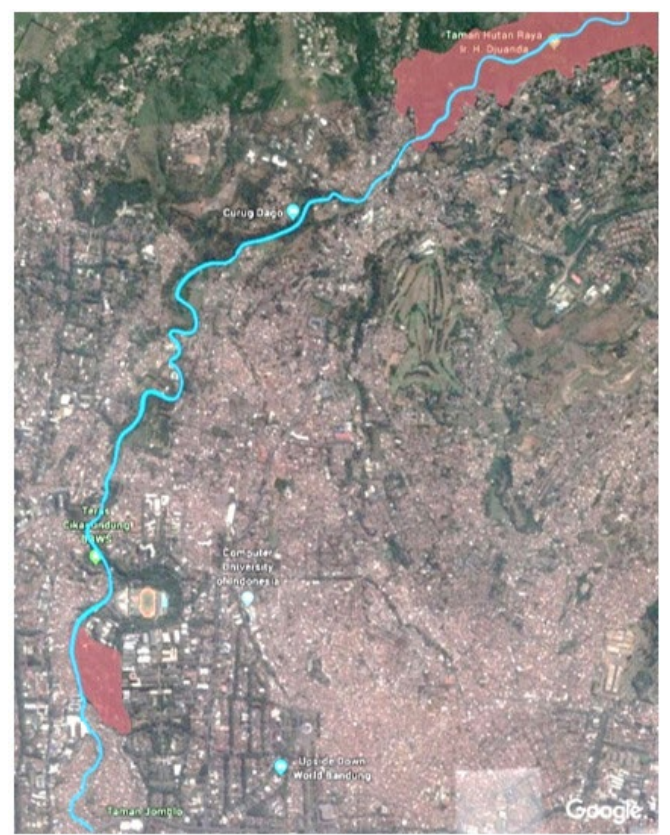

Figure 2. Study area of Cikapundung river (source: google earth 2019) 


\subsection{Methodology}

There are two types of data used in this study, primary and secondary data. Primary data includes landcover of Cikapundung River and Kamo River boundary, obtained through on-screen digitizing from satellite imagery using ArcMap 10.5.1. The satellite image source for Cikapundung and Kamo River is from ArcGIS Imagery/Mercator/WGS84/ EPSG:3395 that obtained from ArcGIS Earth 1.9 SAS Planet. Secondary data includes the biodiversity list of wildlife and plants in the Cikapundung River riparian area; in addition to that, it is the ecological description. The process design of landscaping the Cikapundung wildlife corridor is using SketchUp 2019 and Lumion 2.5 .

\section{Results}

\subsection{Landcover of Cikapundung River}

The landcover digitizing is based on the Bandung Spatial and Regional Planning, which states that the Cikapundung River border's width is at least 10 meters on each right-left side. The landcover is classified into eight classes:

1. Cikapundung River: main river

2. Tree canopy cover: area occupied by tree canopies viewed from above

3. Agriculture: all land covered by agriculture use

4. Grass and shrubs: land covered by understory

5. Field: land with no vegetation covering (mostly by soil)

6. Street: road crosses the river

7. Buildings: all permanent structure with any form by human-made (settlement, roads, cement field, parking lot, and etc.)

8. Others: other than above

The result (Figure 3 ) shows tree canopy has the highest percentage that is $62.2 \%$, followed by buildings $31.0 \%$, agriculture $3.2 \%$, grass and shrubs $3.1 \%$, field $0.5 \%$, and others $0.02 \%$ (Figure 4 ).

\subsection{Biodiversity in Cikapundung River}

Understanding the biodiversity is needed to identify the current conditions and determine the wildlife focal species target need to travel between these patches. Based on the secondary data, it has already listed the potential species target that can be facilitated by developing the Cikapundung wildlife corridor. In total, there are three species of mammals and 23 species of birds. The list is shown in Table 1.

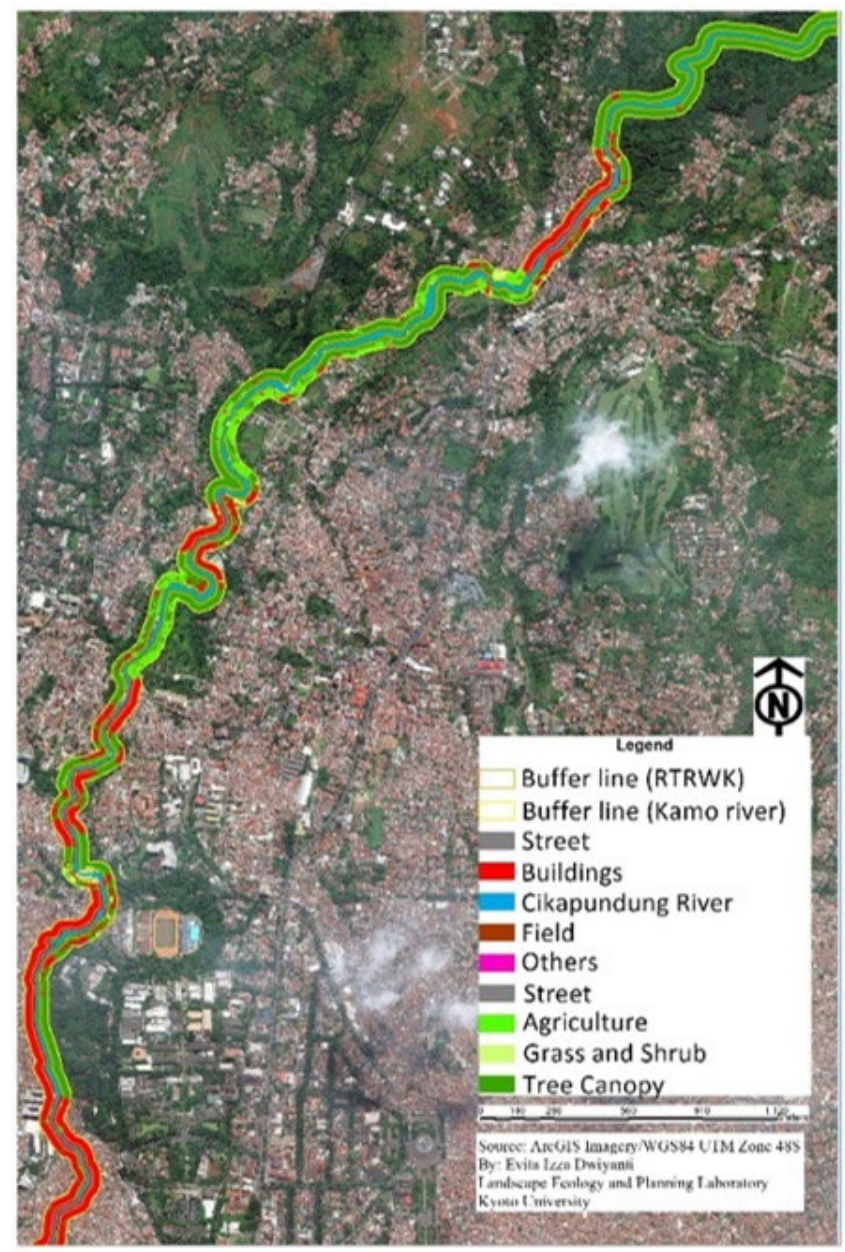

Figure 3. Landcover of Cikapundung river boundary and the zoning priority (yellow line)

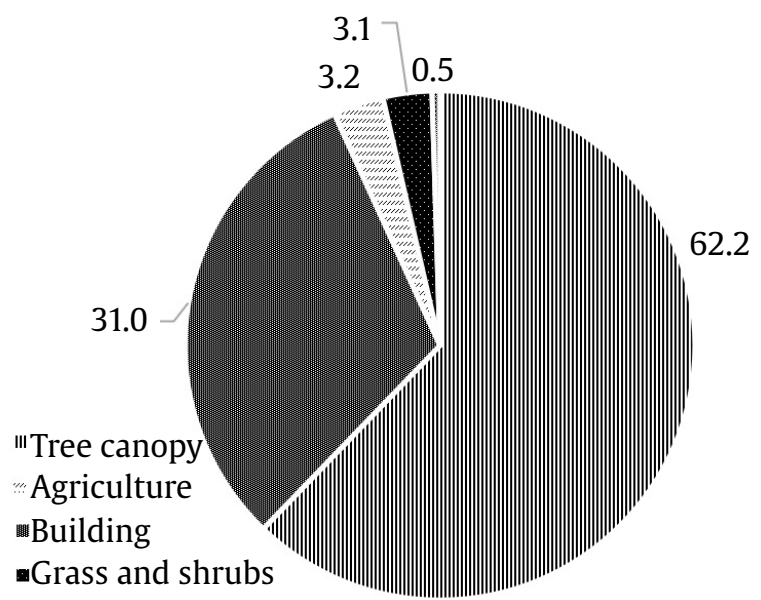

Figure 4. Landcover percentage of Cikapundung river boundary 
Table 1. List of wildlife species focal target

\begin{tabular}{|c|c|c|}
\hline Class & Species & Status $^{1)}$ \\
\hline Mammal & Callosciurus notatus & LC \\
\hline Mammal & $\begin{array}{l}\text { Paradoxurus } \\
\text { hermaphroditus }\end{array}$ & LC \\
\hline Mammal & Pteropus vampyrus & NT \\
\hline Aves & Zosterops palpebrosus & LC \\
\hline Aves & Dicaeum concolor & LC \\
\hline Aves & Halcyon cyanoventris & LC \\
\hline Aves & Gracupica contra & LC \\
\hline Aves & Acridotheres tristis & LC \\
\hline Aves & Apus affinis & LC \\
\hline Aves & Enicurus leschenaulti & LC \\
\hline Aves & Orthotomus sutorius & LC \\
\hline Aves & Geopelia striata & LC \\
\hline Aves & Spilopelia chinensis & LC \\
\hline Aves & Nectarinia jugularis & LC \\
\hline Aves & Lanius schach & LC \\
\hline Aves & $\begin{array}{l}\text { Lonchura } \\
\quad \text { leucogastroides }\end{array}$ & LC \\
\hline Aves & Pycnonotus aurigaster & LC \\
\hline Aves & Cacomantis variolosus & LC \\
\hline Aves & Falco peregrinus & LC \\
\hline Aves & Dicrurus leucophaeus & LC \\
\hline Aves & Muscicapa griseisticta & LC \\
\hline Aves & Spilornis cheela & LC \\
\hline Aves & Dendrocopos macei & LC \\
\hline Aves & Passer montanus & LC \\
\hline Aves & Enicurus velatus & LC \\
\hline Aves & Alcedo coerulescens & LC \\
\hline
\end{tabular}

${ }^{1)}$ Status: Conservation status by IUCN red list species. LC: least concern, NT: near threatened

Source: Suryawan (2011)

\subsection{Landcover of Kamo River}

Kamo is a river passes through Kyoto City, and it is very popular with tourists and residents for many engaging activities such as sightseeing spot during cherry blossoms blooms, picnic, and walking or jogging (Figure 5). Kamo river has a pathway along the river boundary, which is opened for public access. The landcover is divided into four type (Figure 6):

1. River: the main river

2. Tree canopy: area occupied by tree canopies viewed from above

3. Grass and shrubs: area occupied by any vegetation other than tree

4. Field: land with no vegetation covering (mostly by soil)

5. Street: road crosses the river

The highest landcover percentage is field $79.09 \%$, followed by grass and shrubs $21.67 \%$ and tree canopy $18.75 \%$. Most trees are planted on the river border's outer edge, so the center of the river border is filled with soil, or some are overgrown with grass.

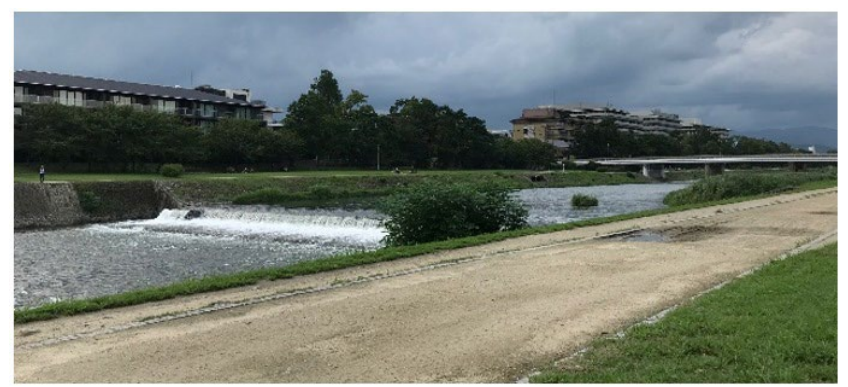

Figure 5. Kamo river

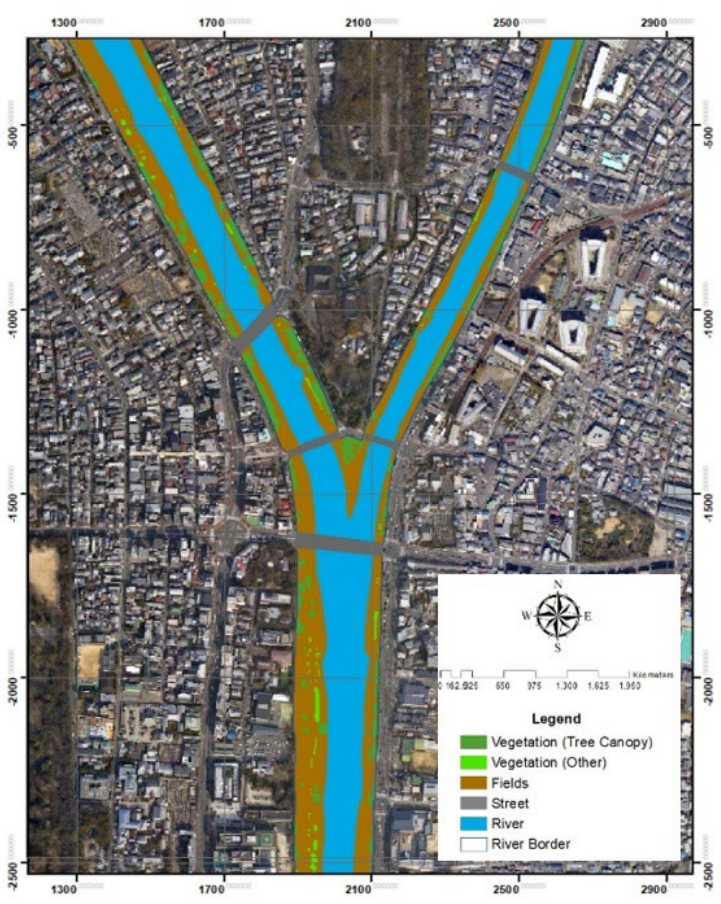

Figure 6. Landcover of kamo river border

\section{Discussion}

\subsection{Comparison between The Cikapundung River and The Kamo River}

Based on the result from Fujino's study (2012) that the number of vegetation species in the Kamo River is dominated by herbaceous/shrubs (96\%), while tree habitus is only $4 \%$ ( 3 species). There is a difference in the number of vegetation species between the Cikapundung River and the Kamo River (Figure 7).

However, the amount of wildlife found in the Kamo River is more significant than in the Cikapundung River (Figure 8). According to Yashiro (2013), there are 41 species of birds found in the Kamo River. Coupled by several pieces of information on websites, several species of mammals were found, such as Venellus cinereus, Myocastor coypus, and wild 


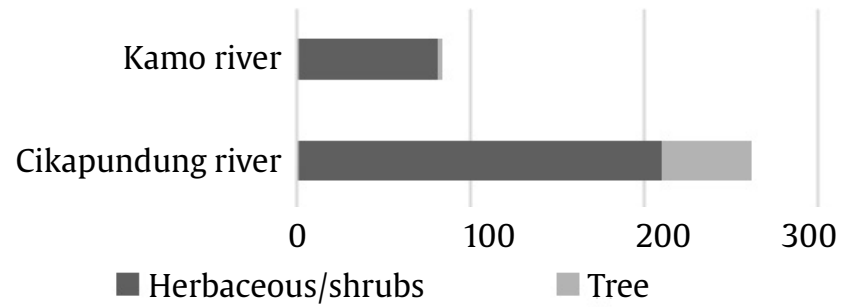

Figure 7. Comparison of vegetation species richness

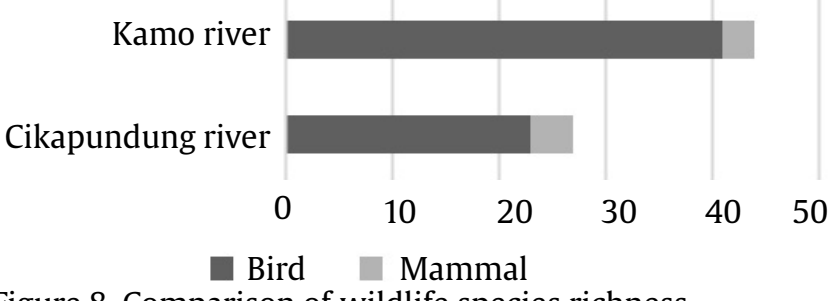

Figure 8. Comparison of wildlife species richness

fawn/deer (Kobayashi and Mihashi 2015; The Kyoto Shimbun 2019).

The dominant species in the Kamo River are wetland birds, such as Egretta alba, Phalacrocorax carbo, and Anas falcata. It is reported by Hua et al. (2012) that as hydrological conditions improved, some waterbirds increased their coverage and became dominant. So, those birds have a vast preference for living in a clean and uncontaminated wetland habitat. It is known that Kamo River's hydrological condition is better than Cikapundung River. Based on biological and chemical analysis, the Cikapundung River has been polluted due to domestic and industrial waste (Surtikanti 2005). Moreover, in contrast, birds living in Cikapundung River are mostly common birds accustomed to living in a disturbed area, such as Geopelia striata, Lonchura leucogastroides, and Passer montanus.

\subsection{The Cikapundung Wildlife Corridor Design}

The corridor is not designed as a linkage solely for any single species, but the wildlife corridor's goal is to conserve or restore a functioning habitat patches network that maintains ecological processes and provides for the movement of all native species (Beier et al. 2007). Due to many bird species categorized as least concern, and most of them are common species in disturbed areas with a similar need, the 23 species of birds will be considered only as 'birds' with a single need (not specific to the species type).

The most critical step in restoring an ecosystem, in this case, is Cikapundung River boundary, is to select the suitable native plant species from the regional species pool. This process needs the ecological information to select appropriate species adapted to the study site (Lu et al. 2017). The process of selecting tree species is adopted from Elliot et al. (2013), called the framework species method. The criteria of the species that will be selected through this method are:

1. Involves planting mixtures of roughly $10 \%$ of the estimated number of tree species in the area (native, not exotic)

2. High survival rates can grow in the full-light and disturbed areas. The mixtures of framework tree species chosen for planting should include both pioneer and climax species. To achieve rapid canopy closure, Goosem and Tucker (1995) recommended that at least $30 \%$ of the planted trees be pioneers

3. Rapid growth

4. Dense, spreading crowns that shade out herbaceous weeds and can support canopy gap closure

5. Have flower, fruits or other resources that can attract wildlife because there is an indication that if a species produces fleshy fruits, or nectar-rich flower, they are likely to attract wildlife

There is 5 step of tree species selection (Figure 9 ). The first selection step is based on the species provenance. There are 52 tree species known in the riparian area of the Cikapundung river (Devi 2017). Fifty species are native to Taman Hutan Raya Ir. $H$. Djuanda or native to West Java, but the rest are invasive species. The second step is based on the tree height. Only plants in the form of tree strata 5 (upper canopy) and 6 (emergent) will be chosen to maximize diversification and increase the complexity of vertical animal distribution in response to horizontal pressure from the development of urban areas (Suryawan 2011). The third step is based on the wildlife attractant (fleshy fruits/nectar-rich flower/ attractive flower). Moreover, the fourth step is based on tree canopy type, which can support canopy gap connection (round, spreading, pyramidal, irregular, and other shapes). The final amount of tree species selected are 14 species (Table 2 ).

\subsection{Tree-planting Techniques}

The techniques will adopt from the manual of tree-planting by Tengnäs (1994) and Elliot et al. (2013). 
Phase 1: 52 species (initial species)

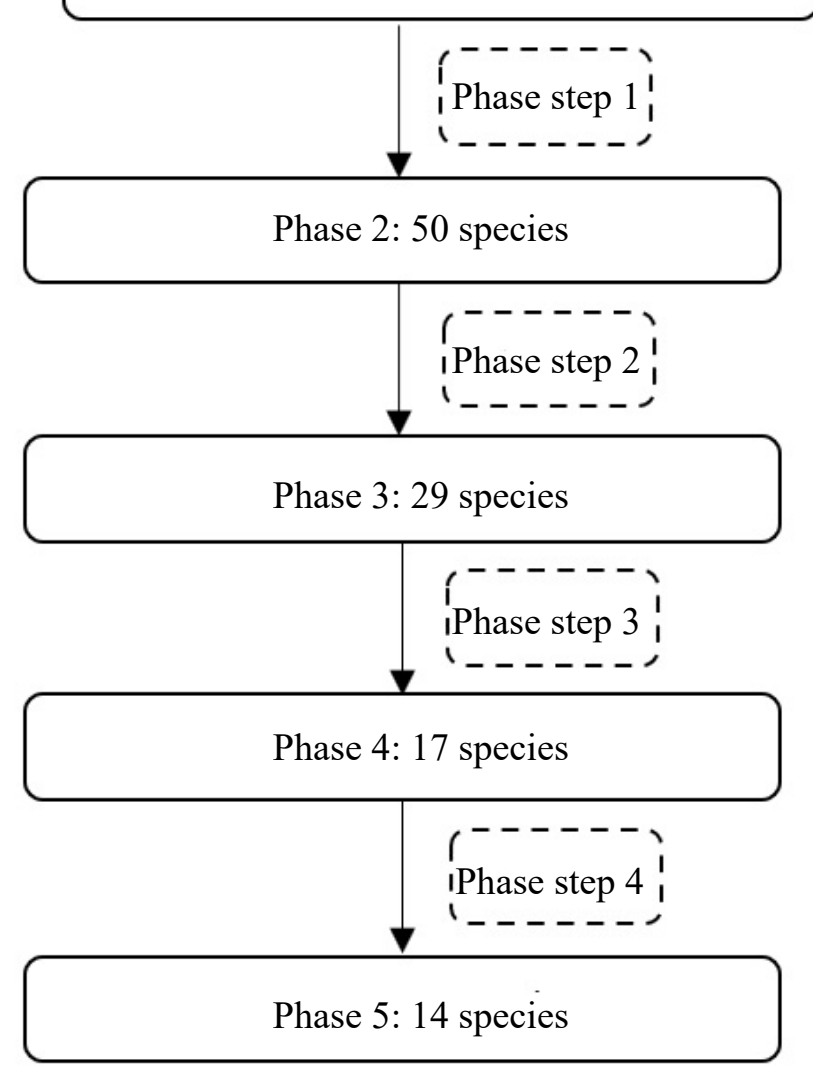

Figure 9. Tree species selection step

\subsubsection{Time of Planting}

It is recommended to start planting during the rainy season and on a cloudy day. The rainy season will moist the soil so the seedlings may not quickly dry out. If necessary, loosen the soil can be done by digging to refill the holes before the rain.

\subsubsection{Site Preparation}

Seedling planting space can be created by digging the soil to form a hole in 30-40 cm depth for each seedling. Trees in the urban forest are often spaced according to the mature canopy spread. The spacing for the trees is a close spacing type (6-9 meters). The advantage of close spacing are quick to form shade and can form a cathedral-like canopy, less pruning of drooping branches required due to upright canopy, and the trees are less susceptible to wind damage. It will be costly than farther spacing, but this type will give a more natural landscape (Gilma 2015).

The topsoil should be separated from the subsoil, and when the hole is going to be filled, the topsoil should be placed nearby the tree roots because of its fertility. A fertilizer like manure, compost, or other organic matter can be used to improve soil fertility.

\subsubsection{Care of Seedlings}

Ideally, seedlings should be about $30 \mathrm{~cm}$ high when they are planted to less competition from weeds. It is recommended to raise the seedlings with a container or pot to prevent soil from retaining around the roots. However, the pot should always be removed at the planting time. It is vital to avoid the roots from direct sunlight.

\subsubsection{How to Plant}

It is essential to consider that the soil surface should be at a level with the overall ground, neither deeper nor higher. After refilling the hole, pack the soil firmly and make sure there is no air space in the soil. Watering is needed if there is no rain. Put some mulch/litter near the seedling to reduce the evaporation of moisture. Based on the land cover, there are two techniques, planting, and enrichment.

Planting techniques are determined on the land cover of buildings, fields, grass and shrubs, and agriculture. The consideration used is that there is no tree in the land cover, so it is assumed that the tree density is 0 trees/ha. The tree canopy density is preferred to facilitate the movement of animals that prioritize movement in vertical areas, such as birds and arboreal mammals. Trees with relatively large and large canopy habitats that can connect one tree to another will provide a movement path that makes it easy for animals in their home range. The lush canopy also provides adequate protection against disturbance and predators (Sulistyadi et al. 2013).

The concept of planting management was adopted from the design of Baskara et al. (1998), namely the concept of green governance. The arrangement of plant collections is designed to resemble an arboretum based on a group of family taxon units in one planting block. This is done to support other functions of the Cikapundung wildlife corridor for public education and visitors. Eight plant families will be placed along Cikapundung River's borderline, namely Altingiaceae, Moraceae, Fabaceae, Annonaceae, Myrtaceae, Malvaceae, Sapindaceae, Verbenaceae. Spacing on planting is $5 \times 5$ meters so that the total final tree density is 400 trees/ha. 


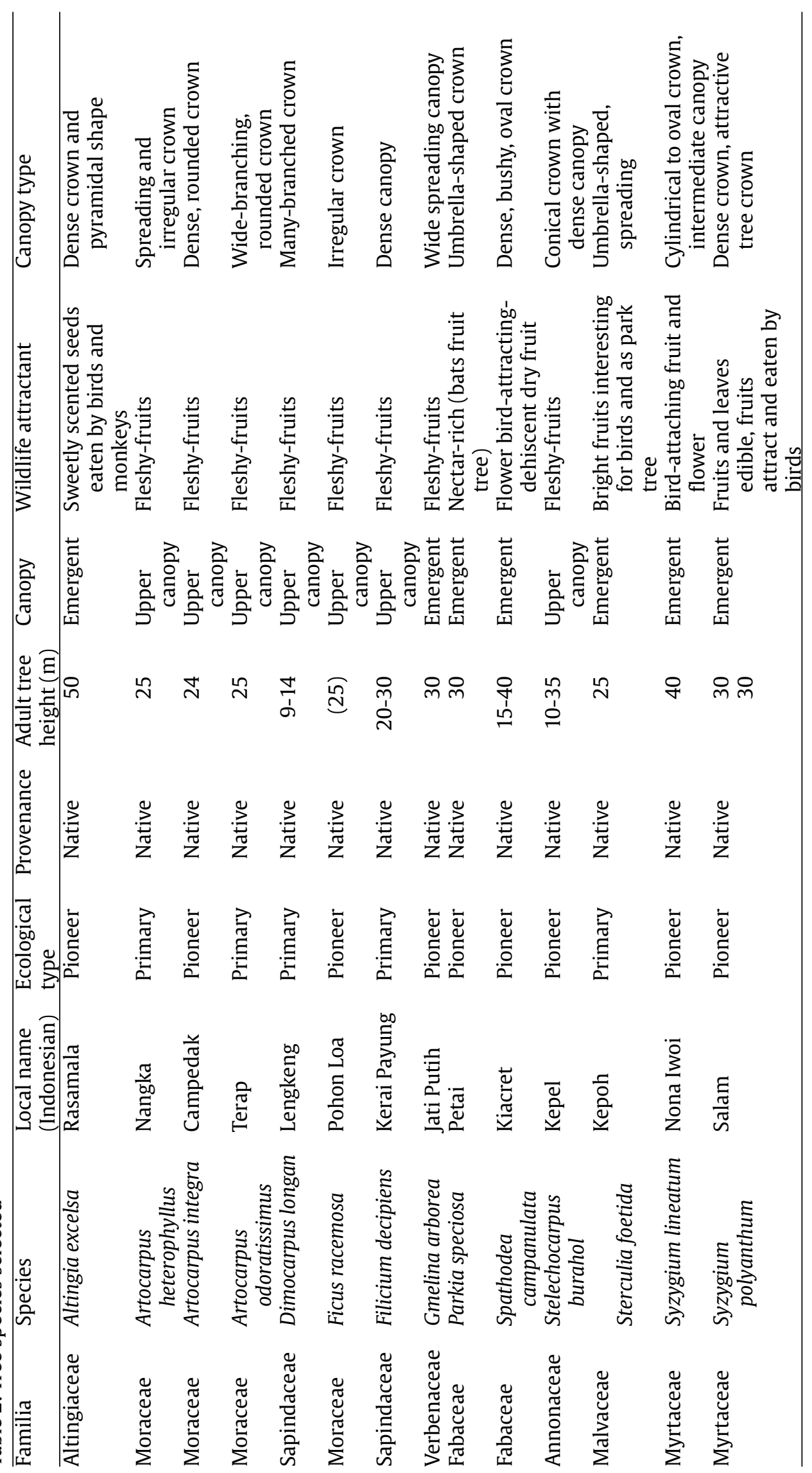




\subsubsection{Care after Planting}

Accelerated Natural Regeneration (ANR) technique enhances the forest's establishment by protecting and nurturing the seedlings. The techniques are:

1. Reducing competition from weeds. Weeding will reduce competition between trees and herbaceous vegetation, increase tree survival and accelerate growth

2. Use of fertilizers. Most tree seedlings and sapling of up to about $1.5 \mathrm{~m}$ tall will respond well to fertilizer applications, regardless of the soil fertility. Fertilizer application both increase survival and accelerate growth and crown development

3. Weeding and fertilization should be applicated for 2 years

It is also essential to protect the seedling from human or livestock trampling and browsing. Protection can be a wooden fence surrounding a plant.

Visualization is done using SketchUp and Lumion to ease the design description (Figure 10). Slum housing around the banks Cikapundung River was relocated and replaced by greenways as Cikapundung wildlife corridor. The river border width of 10 meters is allocated as a location for tree planting ( 8.5 meters) and pedestrian pathways (1.5 meters) that the public can use. Also, some aesthetic vegetation is planted to decorate the landscape and a vegetation buffer and barrier. Some facilities such as park benches, trash bins, and information boards are also added to support public activities.

\section{Conclusion}

Cikapundung River border has several landcover types; the highest percentage of the landcover is tree canopy $62.2 \%$, followed by buildings $31,0 \%$. In the design planning, 14 vegetation species have been selected according to 27 target wildlife species' needs.

A comparison between Cikapundung River and the Kamo River shows Cikapundung River has a more significant number of vegetation species than the Kamo River. However, Kamo River has a more significant number of wildlife species compared to Cikapundung River.

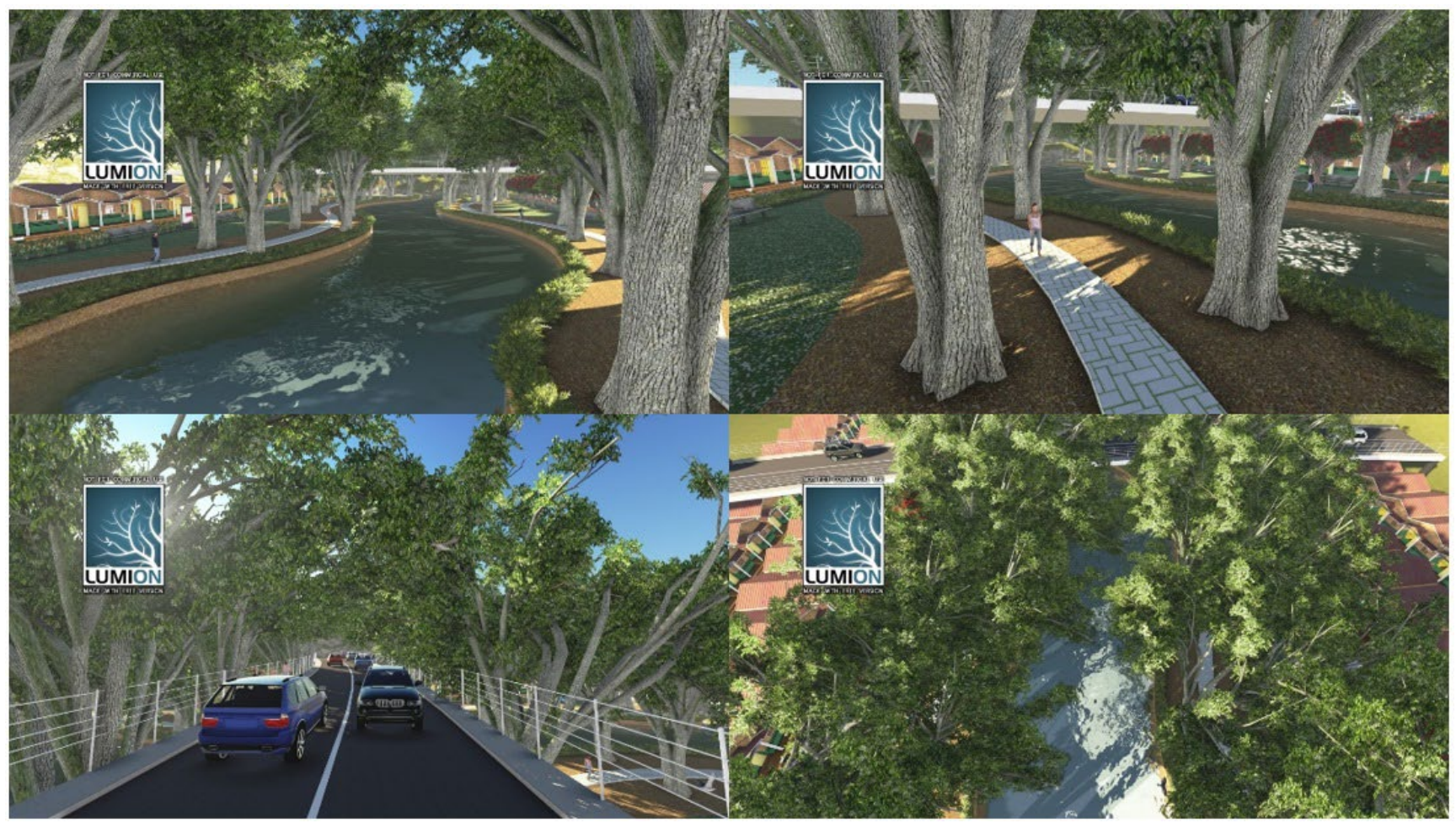

Figure 10. Cikapundung wildlife corridor visualization 


\section{Acknowledgements}

This study was supported by the Graduate School of Global Environmental Studies (GSGES) of Kyoto University; and Japan Student Services Organization (JASSO) for providing a grant to the author to complete the study in Landscape and Ecology Planning lab.

\section{References}

Baskara M et al. 1998. Perencanaan lanskap arboretum sumber brantas sebagai obyek wisata alam. Buletin Taman dan Lanskap Indonesia 1:1-6.

Beier P et al. 2007. Designing Wildlife Corridors with ArcGIS. Watsonville: Corridor Design.

Devi MT. 2017. Vegetasi pada Area Riparian Sepanjang Sungai Cikapundung. Bandung: Institut Teknologi Bandung.

Elliot SD et al. 2013. Restoring Tropical Forests A Practical Guide. Surrey: Kew Publishing.

Fahrig L. 2003. Effects of habitat fragmentation on biodiversity. Ann Rev Ecol Syst 34:487-5151.

Fujino K. 2012. A Case Study on Effect of Environmental Factor in Around Urban River of River Vegetation. Kyoto: Kyoto Prefectural University.

Gilma EF. 2015. Landscape Plants. Available at: http://hort. ifas.ufl.edu/woody [Date accessed: 10 September 2019]

Goosem S, Tucker NI. 2013. Repairing the Rainforest. 2nd ed. North Queensland: Wt Tropics Management Authority and Biotropica Australia Pty. Ltd. Cairns.

Hua Y et al. 2012. Changes in water birds habitat suitability following wetland restoration in the yellow river delta, China. Clean-journal 40:1-9.

Humas Kota Bandung. 2018. Pemkot Bandung Maksimalkan RTH demi Kota Berkelanjutan. Available at: http:// humas.bandung.go.id/humas/layanan/2018-03-22/ pemkot-bandung-maksimalkan-rth-demi-kotaberkelanj [Date accessed: 27 Fabruari 2019]
Kobayashi K,Mihashi A.2015.Kamogawa RiverWildlife.Available at: http://thekyotoproject.org/english/kamogawa-riverwildlife/ [Date accessed: 11 September 2019]

Kusmana C, Hikmat A. 2015. Keanekaragaman hayati flora di Indonesia. Jurnal Pengelolaan Sumberdaya Alam dan Lingkungan 5:187-198.

Luo P et al. 2013. Palaeoflood simulation of the kamo river basin using a grid-cell distributed rainfall run-off model. Flood Risk Management 7:182-192.

Lu Y et al. 2017. Selection of native tree species for subtropical forest restoration in Southwest China. PLOS ONE 12: e0170418. DOI:10.1371/journal.pone.0170418

Soedradjad R. 1999. Lingkungan Hidup (Suatu Pengantar). Jakarta: Universitas Indonesia Press.

Sulistyadi E et al. 2013. Pergerakan lutung jawa Trachypithecus auratus (E. Geoffroy 1812) pada fragmen habitat terisolasi di Taman Wisata Alam Gunung Pancar (TWAGP) Bogor. Berita Biologi 12:383-395.

Surtikanti H. 2005. Kesehatan lingkungan di daerah aliran sungai Cikapundung akibat pencemaran air. JPMIPA 6:9. DOI:10.18269/jpmipa.v6i2.347

Suryawan HS. 2011. Perencanaan Wildlife Corridor pada Bercak Hijau THR Ir. H. Djuanda-Kebun Binatang Bandung dengan Pendekatan Restrafikasi Habitat. Bandung: Tesis Program Studi Arsitektur Institut Teknologi Bandung.

Tengnäs B. 1994. Agroforestry Extension Manual for Kenya Nairobi. Nairobi: International Centre for Research in Agroforestry.

The Kyoto Shimbun, 2019. シカも暑さで水遊び? 京都市 中心部の鴨川に姿見せる. Available at: https://www. kyoto-np.co.jp/local/article/20190530000058 [Date accessed: 11 September 2019]

Yashiro A. 2013. The Ralationship between Avifauna and Surrounding Environment of River on Kamogawa River Basin. Kyoto: Kyoto Prefectural University. 